\title{
IMPLEMENTASI DISIPLIN POSITIF ANAK USIA DINI OLEH PENDIDIK KB BINTANG MULIA KREKAH GILANGHARJO PANDAK BANTUL
}

\author{
${ }^{1}$ Gunartati, ${ }^{2}$ Didik Kurniawan \\ ${ }^{1,2}$ Pendidikan Luar Sekolah STKIP Catur Sakti Yogyakarta \\ Gunartati68@gmail.com
}

\begin{abstract}
ABSTRAK
Penelitian ini bertujuan untuk mendeskripsikan implementasi atau penerapan disiplin positif anak usia dini oleh pendidik di KB Bintang Mulia Krekah dan hasil dari pengimplementasian disiplin positif. Penelitian ini menggunakan metode penelitian kualitatif dengan metode deskriptif. Penelitian ini menggunakan sample purposive. Subjek penelitiannya adalah pendidik dan orang tua di KB Bintang Mulia Krekah dan objek penelitiannya adalah peserta didik yang berjumlah 20 orang. Penelitian ini menggunakan teknik pengambilan data Interview, observasi dan dokumentasi. Tahapan pengujian kredibilitas data menggunakan triangulasi sumber dan triangulasi teknik. Analisis data yang digunakan adalah Miles \& Huberman dengan tahapan reduksi data, data display dan penarikan kesimpulan. Hasil Penelitiannya adalah Pengimplementasian Disiplin Positif dilakukan dengan merencanakan atau menuangkannya dalam RPPH, Pengimplementasian Disiplin Positif dilakukan dengan metode Pembiasaan dan Keteladanan, Pengimplementasian disiplin positif dilakukan dengan menggunakan pendekatan Konstekstual dan saintifik. Bentuk kegiatan berupa kesadaran diri, tanggung jawab dan perilaku prososial

Kata Kunci: Pendidikan Anak Usia Dini, Kelompok Bermain, Disiplin Positif Anak
\end{abstract}

\begin{abstract}
This study aims to describe the implementation or application of positive discipline for early childhood by educators at KB Bintang Mulia Krekah and the results of implementing positive discipline. This research uses qualitative research methods with descriptive methods. This study used purposive sample. The research subjects were educators and parents at KB Bintang Mulia Krekah and the object of the research was 20 students. This study uses interview data retrieval techniques, observation and documentation. The stages of testing the credibility of the data used triangulation of sources and triangulation of techniques. The data analysis used was Miles \& Huberman with the stages of data reduction, data display and conclusion drawing. The result of the research is that the implementation of positive discipline is carried out by planning or pouring it into RPPH, the implementation of positive discipline is carried out by the habituation and example method, the implementation of positive discipline is carried out using a contextual and scientific approach. Activities in the form of selfawareness, responsibility and prosocial behavior.
\end{abstract}

Keywords: Early Childhood Education, Play Group, Child Positive Dicipline 


\section{PENDAHULUAN}

Penerapan disiplin positif dilaksanakan di KB Bintang Mulia, mulai disiplin untuk anakanak dan disiplin bagi pendidik serta wali murid. Disiplin dilakukan di antaranya disiplin waktu dan disiplin dalam bertanggungjawab. Terkait dengan hal tersebut diatas penulis mencoba untuk bisa memberikan kontribusi didalam pengasuhan disiplin positif kepada anak usia dini. Maka dari itu, diperlukan suatu cara/sistem yang sesuai untuk kebutuhan mereka. penulis berharap dengan adanya cara/sistem yang sesuai anak-anak dapat tumbuh dan berkembang secara optimal dengan minat dan bakat mereka masing-masing sesuai dengan potensi yang mereka miliki. Pada keadaan tersebut, di KB Bintang Mulia masih memerlukan sumber daya manusia yang memadai untuk pengasuhan disiplin positif. Dalam hal ini, KB Bintang Mulia berusaha mengembangkan pendidiknya dengan membekalinya melalui pelatihan tentang pengasuhan dan melanjutkan studi sesuai dengan kompetensinya.

Berdasarkan hasil observasi awal di KB Bintang mulia telah menerapkan disiplin positif di antaranya 1) disiplin sehari-hari, seperti disiplin membereskan alat main setelah kegiatan bermain dan belajar, mengembalikan buku ke rak yang sudah disediakan, dan mengembalikan LKA di loker masing-masing anak, 2) Disiplin sopan santun, seperti menghormati orang di sekitar, meminta izin ketika akan melakukan kegiatan, meminta maaf ketika berbuat salah, dan berterimakasih ketika dibantu atau diberi sesuatu oleh orang lain. 3) Disiplin waktu, seperti datang tepat waktu ke sekolah, menyelesaikan permainan tepat waktu serta bertanggungjawab. Selain pendidik yang memberikan ilmu tentang kedisiplinan kepada anak, pihak lembaga KB Bintang mulia juga bekerjasama dengan orang tua untuk turut serta dalam melakukan pembiasaan disiplin positif pada saat di lingkungan rumah.

Penerapan disiplin positif diterapkan di KB Bintang Mulia sejak tahun 2017. Pertama kali diterapkan dengan pelaksanaan kegiatan sosialisasi pengasuhan disiplin positif. Orang tua terlihat sangat antusias dan orang tua yang belum begitu paham tentang pengasuhan disiplin positif diberikan kebebasan dengan cara berkonsultasi atau sharing. Penerapan Disiplin positif di KB Bintang Mulia diterapkan dengan metode pembiasaan dan keteladanan. Dalam penerapannya pihak lembaga KB Bintang mulia juga membutuhkan kerjasama antara sekolah, pendidik, orang tua, dan masyarakat.

Selanjutnya penelitian ini dilaksanakan secara keseluruhan bukan menitikberatkan pada satu anak saja. Maka dari itu, dalam penelitian ingin meneliti atau mengetahu lebih lanjut tentang penerapan disipli positif di KB Bintang Mulia. Adapun judul penelitian yang diambil adalah "Implementasi Disiplin Positif Anak Usia Dini Oleh Pendidik KB Bintang Mulia Krekah Gilangharjo Pandak Bantul".

\section{KAJIAN TEORI}

\section{Implementasi Disiplin Positif}

Menurut Nurdin Usman (2002), "implementasi adalah bermuara pada aktivitas aksi, tindakan atau adanya mekanisme suatu sistem, implementasi bukan sekedar aktivitas, tapi suatu kegiatan yang terencana dan untuk mencapai tujuan kegiatan. Selanjutnya, Guntur Setiawan (2004: 39) berpendapat, implementasi adalah perluasan aktivitas yang saling menyesuaikan proses interaksi antara tujuan dan tindakan untuk mencapainya serta memerlukan jaringan pelaksana birokrasi yang efektif. 
Dari pengertian-pengertian diatas memperlihatkan bahwa kata implementasi bermuara pada mekanisme suatu sistem. Berdasarkan pendapat para ahli di atas maka dapat disimpulkan implementasi adalah suatu kegiatan yang terencana, bukan hanya suatu aktifitas dan dilakukan secara sungguh-sungguh berdasarkan acuan norma-norma tertentu untuk mencapai tujuan kegiatan.

Menurut Agus Wibowo (2012), "untuk menerapkan disiplin positif kepada anak, maka anak harus mempunyai karakter baik". Berikut ini ada beberapa peran yang harus dilakukan oleh pendidik PAUD dan orang tua dalam membangun karakter anak usia dini, di antaranya adalah

1) Memperlakukan anak sesuai dengan karakteristiknya

Dengan memahami keunikan itu, maka orang tua dan pendidik PAUD akan memberikan stimulus entah berupa bimbingan, pelatihan, pendidikan, maupun pengkondisian akan tepat sasaran dan efektif terhadap anak.

2) Memenuhi kebutuhan dasar anak, seperti kebutuhan kasih sayang dan pemberian makanan yang bergizi.

3) Pola pendidik PAUD dengan orang tua yang dilaksanakan baik di rumah dan di sekolah hendaknya saling berkaitan.

4) Peran orang tua dan pendidik PAUD hendaknya memberikan dukungan dan penghargaan ketika anak menampilkan tingkah laku yang terpuji.

5) Orang tua dan pendidik PAUD hendaknya memberikan fasilitas lingkungan yang sesuai dengan usia perkembangan anak.

6) Orang tua dan pendidik PAUD harus bersikap tegas, konsisten dan bertanggung jawab.

\section{Pengaruh Penerapan Disiplin Positif}

Elizabeth B. Hurlock (2011), “penerapan disiplin positif ini berpengaruh terhadap anakanak". Beberapa pengaruhnya adalah

1) Pengaruh pada perilaku

Anak yang orang tuanya lemah akan mementingkan dirinya senditi, tidak menghiraukan hak-hak orang lain, agresif dan tidak sosial. Anak yang mengalami disiplin yang keras, otoriter akan sangat patuh bila dihadapan orang-orang dewasa, namun agresif dalam hubungan dengan teman-teman sebayanya. Anak yang dibesarkan di bawah disiplin demokratis belajar mengendalikan perilaku yang salah dan mempertimbangkan hak-hak orang lain.

2) Pengaruh pada sikap

Anak yang orang tuanya melaksanakan disiplin otoriter maupun disiplin yang lemah cenderung membenci orang-orang yang berkuasa. Anak yang mengalami disiplin otoriter merasa diperlakukan tidak adil, anak yang orang tuanya lemah merasa bahwa orang tua seharusnya memperingatkan bahwa tida semua orang dewasa mau menerima perilaku yang tidak disiplin. Disiplin demokratis dapat menyebabkan kemarahan sementara tetapi bukan kebencian. Sikap-sikap yang berbentuk sebagai akibat dari metode pendidik anak cenderung menetap dan bersifat umum, tertuju kepada semua orang yang berkuasa.

3) Pengaruh pada Keperibadian 
Semakin banyak hukuman fisik digunakan, semakin anak cenderung menjadi cemberut karena negativistic. Ini mengakibatkan penyesuaian keperibadian sosial yang buruk, yang juga merupakan ciri khas dari anak yang dibesarkan dengan disiplin yang lemah. Anak yang dibesarkan di bawah disiplin yang demokratis akan mempunyai penyesuaian pribadi dan penyesuaian sosial yang terbaik.

Menurut Agus Wibowo (2012), "untuk menerapkan disiplin positif kepada anak, maka anak harus mempunyai karakter baik". Berikut ini ada beberapa peran yang harus dilakukan oleh pendidik PAUD dan orang tua dalam membangun karakter anak usia dini, di antaranya adalah

1) Memperlakukan anak sesuai dengan karakteristiknya

2) Memenuhi kebutuhan dasar anak, seperti kebutuhan kasih sayang dan pemberian makanan yang bergizi.

3) Pola pendidik PAUD dengan orang tua yang dilaksanakan baik di rumah dan di sekolah hendaknya saling berkaitan. Peran orang tua dan pendidik PAUD hendaknya memberikan dukungan dan penghargaan ketika anak menampilkan tingkah laku yang terpuji.

4) Orang tua dan pendidik PAUD hendaknya memberikan fasilitas lingkungan yang sesuai dengan usia perkembangan anak.

Orang tua dan pendidik PAUD harus bersikap tegas, konsisten dan bertanggung jawab.

\section{Anak Usia Dini}

"Anak usia dini adalah anak yang berada pada rentan usia 0-6 tahun (Undang-undang Sisdiknas tahun 2003) dan 0-8 tahun menurut para pakar pendidikan anak" (Departemen Pendidikan Nasional, 2007). Menurut Mansur (2005: 88) "anak usia dini adalah kelompok anak yang berada dalam proses pertumbuhan dan perkembangan yang bersifat unik". Mereka memiliki pola pertumbuhan dan perkembangan yang khusus sesuai dengan tingkat pertumbuhan dan perkembangannya. Pada masa ini merupakan masa emas atau golden age, karena anak mengalami pertumbuhan dan perkembangan yang sangat pesat dan tidak tergantikan pada masa mendatang. "Menurut berbagai penelitian di bidang neurologi terbukti bahwa 50\% kecerdasan anak terbentuk dalam kurun waktu 4 tahun pertama. Setelah anak berusia 8 tahun perkembangan otaknya mencapai $80 \%$ dan pada usia 18 tahun mencapai 100\%" (Slamet Suyanto, 2005).

Sesuai dengan Undang-undang Sisdiknas tahun 2003 pasal 1 ayat 14, upaya pembinaan yang ditujukan bagi anak usia 0-6 tahun tersebut dilakukan melalui Pendidikan anak usia dini (PAUD). Pendidikan anak usia dini dapat dilaksanakan melalui pendidikan formal, nonformal dan informal. Pendidikan anak usia dini jalur formal berbentuk taman kanak-kanak (TK) dan Raudatul Athfal (RA) dan bentuk lain yang sederajat. Pendidikan anak usia dini jalur nonformal berbentuk kelompok 9 bermain (KB), taman penitipan anak (TPA), sedangkan PAUD pada jalur pendidikan informal berbentuk pendidikan keluarga atau pendidikan yang diselenggarakan lingkungan seperti bina keluarga balita dan posyandu yang terintegrasi PAUD atau yang kita kenal dengan satuan PAUD sejenis (SPS). "Maleong menyebutkan bahwa ragam pendidikan untuk anak usia dini jalur non formal terbagi atas tiga kelompok yaitu kelompok taman penitipan anak (TPA) usia 0-6 tahun); kelompok bermain (KB) usia 2-6 tahun; kelompok satuan PAUD sejenis (SPS) usia 0-6 tahun" (Harun Rasyd, dkk, 2009).

Dari uraian di atas, penulis menyimpulkan bahwa anak usia dini adalah anak yang berada 
pada rentang usia 0-6 tahun yang sedang mengalami pertumbuhan dan perkembangan yang sangat pesat, sehingga diperlukan stimulasi yang tepat agar dapat tumbuh dan berkembang dengan maksimal. Pemberian stimulasi tersebut harus diberikan melalui lingungan keluarga, PAUD jalur non formal seperti tempat penitipan anak (TPA) atau kelompok bermain (KB) dan PAUD jalur formal seperti TK dan RA.

\section{METODOLOGI}

Dalam penelitian ini, penulis menggunakan metode deskriptif, yaitu kegiatan yang dilakukan untuk menggambarkan kondisi yang dilihat dalam lapangan secara apa adanya, datadata mengenai hal-hal yang diselidiki/diteliti kemudian dianalisa. Subjek penelitian adalah tempat diadakannya penelitian, yaitu pendidik di Kelompok Bermain Bintang Mulia. Data subjek penelitian berjumlah 2 orang pendidik untuk diwawancarai cara mengimplementasikan Disiplin Positif Anak Usia Dini Oleh Pendidik KB Bintang Mulia Krekah Gilangharjo Pandak Bantul dan 24 peserta didik sebagai subjek observasi. Sedangkan objek penelitian adalah informasi atau masalah yang ingin diketahui dari sumber berkaitan dengan Implementasi Disiplin Positif Anak Usia Dini Oleh Pendidik KB Bintang Mulia Krekah Gilangharjo Pandak Bantul.

Sugiyono (2012: 217) memaparkan bahwa "teknik sampling adalah teknik pengambilan sampel, untuk menentukan sampel yang akan digunakan dalam penelitian, terdapat berbagai teknik sampling yang digunakan Dalam penelitian ini teknik pengambilan sampel yang digunakan oleh punulis adalah purposive sampling. Penulis menggunakan teknik pengumpulan data dengan melakukan (1) wawancara; (2) observasi; (3) dokumentasi.

\section{HASIL PENELITIAN DAN PEMBAHASAN}

\section{Hasil}

Hasil penelitian implementasi Disiplin Positif Anak Usia Dini oleh Pendidik.

\section{Wawasan tentang Disiplin Positif}

Disiplin positif merupakan suatu pendekatan dalam mendidik anak untuk melakukan kontrol diri dan pembentukan kepercayaan diri. Disiplin sebenarnya berbeda sekali dengan hukuman meskipun disiplin diterapkan dengan menggunakan teknik hukuman.

\section{Tujuan Pengimplementasian Disiplin Positif Anak Usia Dini}

Penerapan disiplin positif anak usia dini bertujuan kehidupan yang lebih baik, menjadikan anak taat aturan, terbiasa berperilaku yang mencerminkan sikap bertanggung jawab. Diterapkannya disiplin positif berguna juga untuk kebahagiannya sendiri, terutama yang berhubungan dengan keterampilan sosial dan self esteem atau yang sering disebut dengan konsep diri.

\section{Implementasi Disiplin Positif}

Membangun disiplin positif bisa diawali dengan langkah-langkan mengidentifikasi permasalahan ataupun kesalahan anak. Seorang pendidik harus mengidentifikasi kesalahan anak terlebih dahulu sebelum melakukan tindakan terhadap anak. Dalam pengimplementasian disiplin positif kita juga memerlukan beberapa metode atau pendekatan. 


\section{a. Metode yang Digunakan dalam Mengimplementasikan Disiplin Positif}

Metode merupakan suatu prosedur atau cara yang ditempuh untuk mencapai tujuan tertentu. Metode dalam pengimplementasian disiplin positif yang digunakan untuk anak usia dini harus sesuai dengan usianya. Usia yang berbeda tentu memiliki karakteristik yang berbeda. Metode yang digunakan untuk membentuk disiplin di usia 2-4 tahun tentu sangat berbeda dibandingkan dengan metode yang digunakan untuk membentuk disiplin positif pada usia 12 sampai dengan 18 tahun.

\section{b. Pendekatan yang Digunakan dalam Mengimplementasikan Disiplin Positif}

Pendekatan diartikan sebagai titik tolak atau sudut pandang kita terhadap proses pembelajaran yang merujuk pada pandangan tentang terjadinya suatu proses yang sifatnya sangat umum. Pendekatan pembelajaran terbagi menjadi 10 macam jenis, yaitu pendekatan konstektual (CTL), Konstruktive, deduktif, induktif, konsep, proses, pendekatan Open Ended, pendekatan saintifik, pendekatan realistic, pendekatan sains, teknologi dan masyarakat. Pada KB Bintang Mulia Krekah menggunakan pendekatan kontekstual dan scintifik.

\section{c. Peran pendidik dalam Mengimplementasikan Disiplin Positif}

Pendidik PAUD tidak hanya berperan pada aspek akademik saja. Pendidik berperan dalam hal pembelajaran (dari proses perencanaan, pelaksanaan hingga evaluasi), berperan dalam proses administrasi kelas dan berperan dalam psikologis anak (proses pencegahan, penanganan, hingga rehabilitas).

\section{Bentuk Implementasi Disiplin Positif}

Implementasi disiplin positif pada anak usia dini diterapkan dengan menggunakan kegiatan kehidupan sehari-hari. Kegiatan tersebut biasanya berkaitan dengan melatih tanggung jawab, kesadaran diri dan perilaku prososial.

\section{Hambatan Penanaman Disiplin Positif Anak Usia Dini}

Dalam pengimplementasian disiplin positif juga sering kali terjadi beberapa faktor penghambat. Berdasarkan hasil wawancara di atas dapat disimpulkan bahwa faktor penghambat terjadi karena hal-hal sebagai berikut :

a. Belum semua orang tua mengetahui tentang disiplin positif secara menyeluruh, sehingga perlu diadakannya kegiatan parenting disiplin positif.

b. Beberapa orang tua sudah mengetahui tentang disiplin positif namun tidak mau saling berbagai atau sering kesulitan untuk bertemu dan melaksanakan kegiatan sharing, sehingga perlu dikumpulkan untuk melaksanakan kegiatan sharing atau tukar pendapat.

c. Peserta didik masih sulit dikendalikan, sehingga masih harus dibiasakan dan dicontohkan. Oleh karena itu, perlu adanya kegiatan home visit.

\section{Perkembangan Disiplin Positif Anak Usia Dini}

Perkembangan merupakan suatu proses yang bersifat kualitatif dan berhubungan dengan kematangan seorang individu yang ditinjau dari perubahan yang bersifat progresif serta sistematis di dalam diri manusia. 


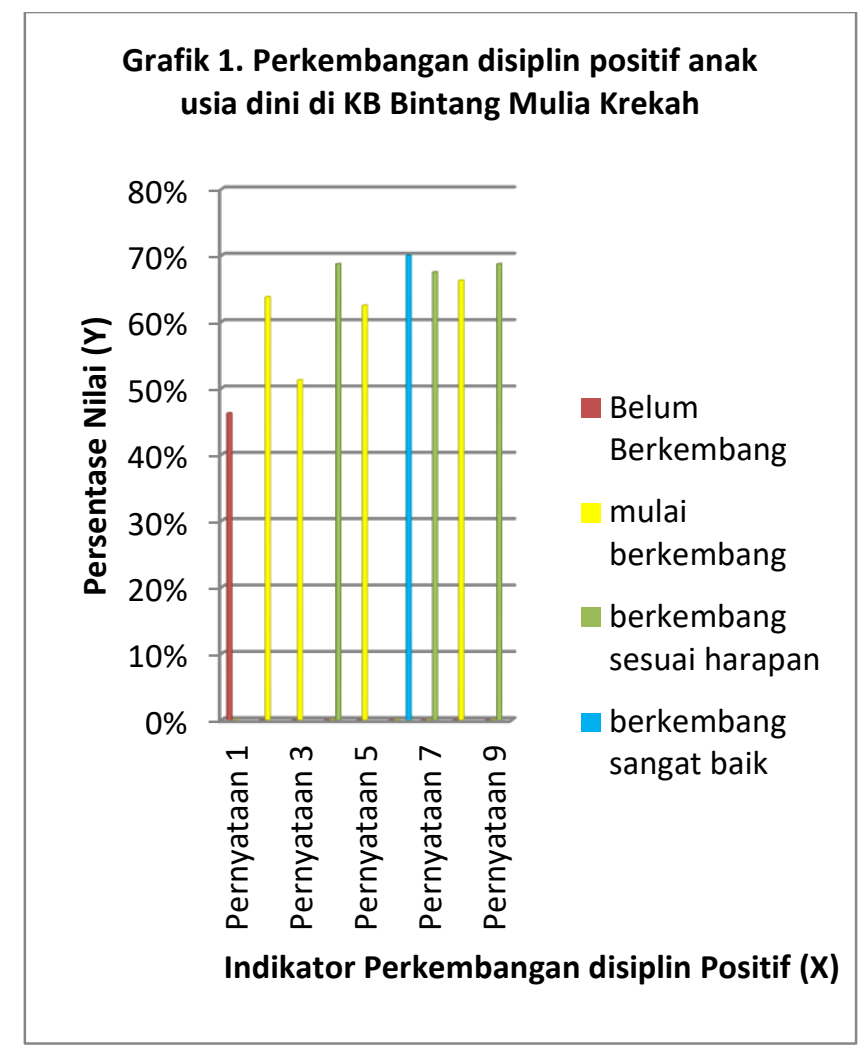

Dari grafik 1 diatas, dijelaskan bahwa peserta didik dalam perkembangan perilaku yang mencerminkan sikap disiplin positif, yaitu pada pernyataan 1 mereka mau duduk mengikuti pembelajaran pada indikator aktif mengikuti pembelajaran memperoleh skor persentase sebanyak $46.25 \%$ dengan kategori belum berkembang. Nilai skor tersebut menggambarkan peserta didik belum bisa fokus pada pembelajaran, mereka masih suka berlari-larian, mereka masih suka menjaili temannya dan lain sebagainya.

Kemudian dalam perkembangan perilaku yang mencerminkan sikap disiplin positif, yaitu peserta didik berani bertanya ketika tidak paham dengan materi yang dipelajari pada indikator aktif mengikuti pembelajaran memperoleh skor persentase sebanyak $63.75 \%$ dengan kategori mulai berkembang. Nilai skor tersebut menggambarkan. Selanjutnya, perkembangan perilaku yang mencerminkan sikap disiplin positif adalah peserta didik mengerjakan tugas dengan tuntas dan tepat waktu pada indikator tanggung jawab memperoleh skor persentase sebanyak $51.25 \%$ dengan kategori Mulai Berkembang.

Perkembangan peserta didik dalam perilaku yang mencerminkan sikap disiplin positif adalah peserta didik terbiasa untuk mengucapkan terimakasih pada saat diberikan sesuatu pada indikator tanggung jawab memperoleh skor persentase sebanyak $68.75 \%$ dengan kategori Berkembang sesuai harapan. Perkembangan peserta didik dalam perilaku yang mencerminkan sikap disiplin positif adalah peserta didik terbiasa mengucapkan maaf ketika melakukan kesalahan dan memaafkan ketika teman meminta maaf pada indikator tanggung jawab memperoleh skor persentase sebanyak 62.50\% dengan kategori Mulai Berkembang.

Begitu juga dengan perkembangan berperilaku disiplin positif, yaitu peserta didik terbiasa mengucapkan salam sebelum dan sesudah sekolah dengan pendidik pada indikator mengamalkan tata tertib yang ada di sekolah sebanyak 70.00\% dengan kategori Berkembang sesuai harapan. Selanjutnya, begitu juga dengan perkembangan berperilaku disiplin positif, 
yaitu Peserta didik terbiasa untuk antri atau menunggu giliran pada saat melakukan kegiatan pada indikator mengamalkan tata tertib yang ada di sekolah sebanyak $67.50 \%$ dengan kategori Mulai Berkembang.

Kemudian, peserta didik mengikuti aturan bermain yang sudah disepakati pendidik dan peserta didik pada indikator mengamalkan tata tertib yang ada di sekolah sebanyak $66.25 \%$ dengan kategori Mulai Berkembang. Selanjutnya, membereskan peralatan main setelah kegiatan main selesai pada indikator mengamalkan tata tertib yang ada di sekolah sebanyak 68.75\% dengan kategori Berkembang sesuai harapan. Jadi, dari 9 pernyataan di atas merupakan perkembangan pelaksanaan disiplin positif. Disiplin positif erat kaitannya dengan penanaman aspek perkembangan nilai agama dan moral serta sosial emosinalnya. Pelaksanaan disiplin positif juga merupakan suatu cara untuk pembentukan karakter sejak usia dini.

\section{Pembahasan}

Disiplin positif harus masuk akal bagi seorang anak. Disiplin positif harus selalu berhubungan dengan kenakalan anak, karena suatu kesalahan tidak selalu merupakan kenakalan. Disiplin membantu anak merasa nyaman dengan dirinya sendiri. Peran pendidik dan orang tua dalam pengimplementasian disiplin positif adalah sebagai pendidik, panutan dan moderator. Berikut ini peran pendidik dan orang tua dalam proses menanamkan disiplin positif.

1. Pendidik dan/atau orang tua berperan sebagai pendidik

Pendidik dan orang tua bukan sekedar orang yang mentransfer ilmu ke anak-anak, namun lebih dari itu. Pendidik atau orang tua merupakan orang yang berperan memberikan konsep ilmu bahkan pembentukan sikap dan perilaku. Pendidik dan/atau orang tua secara langsung membuat rancangan pengembangan perilaku disiplin pada anak, melaksanakan dan mengembangkannya sehingga menjadi cara hidup anak.

Pendidik dan/atau orang tua harus memamahi karakteristik anak sesuai usianya, budaya dan lingkungannya, sehingga apa yang disampaikan tidak terlalu jauh dengan kehidupan anak sehari-hari. Hal tersebut juga agar perilaku yang akan kita tanamkan dapat diamati dan ditiru sesuai sifatnya sebagai pengamat dan peniru.

2. Pendidik dan/atau orang tua sebagai panutan

Pendidik PAUD adalah salah orang yang paling dekat dengan hidup anak, karenanya setiap sikap yang terlihat dari pendidik akan dicontoh anak. Anak belum mampu memilih perilaku mana yang boleh ditiru dan yang tidak. Setiap perilaku yang teramati oleh anak, dianggapnya sebagai perilaku yang boleh ditiru. Pendidik perlu memahami bagaimana bersikap dan berperilaku di depan anak-anak agar sikap dan perilaku yang dicontoh anak adalah perilaku yang diharapkan tertanam pada anak saja. Anak paling mudah mempelajari sesuatu dari mengamati dan meniru, terutama dalam menanamkan karakter ini. Cara paling mudah menanamkan karakter adalah melalui pembiasaan perilaku yang diharapkan tersebut dalam setiap aktivitas anak. Keberhasilan pembiasaan akan menentukan keberhasilan pembentukan karakter anak yang berpengaruh pada pembentukan karakter bangsa nantinya.

3. Pendidik dan atau orang tua sebagai mediator

Pendidik PAUD, terutama pendidik, merupakan orang yang paling benar di mata anak-anak sehingga dijadikan tempat untuk mengadukan segala kesulitan yang dialaminya. Pendidik 
dijadikan tempat berbagi paling aman bagi anak. Karenanya pendidik perlu memiliki kemampuan menyelesaikan permasalahan anak ketika mereka mengadu. Jika ada konflik diantara sesama anak, penddidik perlu mencari tahu sebab konflik tersebut sebelum menyelesaikannya. Disini akan tertanam sikap jujur, berani, dan bertanggung jawab.

Selanjutnya, metode yang digunakan dalam implementasi disiplin postif adalah pembiasaan dan keteladanan. Di dalam buku Kurikulum 2013 juga disebutkan bahwa pembiasaaan atau keteladan merupakan metode yang tepat digunakan untuk mengajari anak usia dini. Sedangkan pendekatan yang digunakan adalah konstektual dan saintifik.

\section{KESIMPULAN}

Berdasarkan hasil penelitian dan pembahasan tersebut di atas, maka hasil penelitian tentang Implementasi disiplin positif anak usia dini oleh pendidik di KB Bintang Mulia Krekah Gilangharjo Pandak Bantul, sebagai berikut :

1. Implementasi disiplin positif anak usia dini di KB Bintang mulia krekah dengan merencanakan atau menuangkannya ke dalam rencana pelaksanaan pembelajaran harian, menggunakan metode pembiasaan, keteladanan, pendekatan konstektual dan sainsitifik. Bentuk kegiatan berupa penerapan kesadaran diri, tanggung jawab dan perilaku prososial.

2. Peran pendidik dan orang tua dalam penanaman disiplin positif di KB Bintang Mulia Krekah sebagai berikut :

a. Pendidik dan orang tua berperan sebagai pendidik

b. Pendidik dan orang tua berperan sebagai panutan

c. Pendidik dan orang tua berperan sebagai mediator

3. Hambatan penanaman disiplin positif dan cara mengatasinya, sebagai berikut :

a. Belum semua orang tua mengetahui tentang disiplin positif secara menyeluruh, sehingga perlu diadakannya kegiatan parenting disiplin positif.

b. Beberapa orang tua sudah mengetahui tentang disiplin positif namun tidak mau saling berbagai atau sering kesulitan untuk bertemu dan melaksanakan kegiatan sharing, sehingga perlu dikumpulkan untuk melaksanakan kegiatan sharing atau tukar pendapat.

c. Peserta didik masih sulit dikendalikan, sehingga masih harus dibiasakan dan dicontohkan. Oleh karena itu, perlu adanya kegiatan home visit

\section{SARAN}

Setelah mengadakan penelitian dan pengkajian tentang implementasi disiplin positif anak usia dini di sebuah lembaga pendidikan, serta dihadapkan pada sebuah krisis karakter bahwa tugas untuk mendidik bukan hanya datang dari pendidik melainkan semua pihak. Oleh karena itu hendaknya timbul kesadaran dan kerja sama dari berbagai pihak seperti masyarakat dan pemerintah, dan tentunya sekolah. Bukan hanya untuk mengejar prestasi di mata dunia namun juga menciptakan generasi yang memiliki kepribadian yang patut untuk dibanggakan. 


\section{DAFTAR PUSTAKA}

Agus Wibowo. 2012. Pendidikan Karakter Usia Dini : Strategi Membangun Karakter di Usia Emas. Yogyakarta : Pustaka Pelajar.

Departeman Pendidikan Nasional. 2007. Pedoman Pembelajaran Bidang Pengembangan Berbahasa di Taman Kanak-Kanak. Jakarta: Departemen Pendidikan Nasional Direktorat Jenderal Manajemen Pendidikan Dasar dan Menengah Direktorat Pembinaan Taman Kanak-Kanak dan Sekolah Dasar.

Guntur Setiawan. 2004. Impelemtasi dalam Birokrasi Pembangunan. Jakarta : Balai Pustaka

Harun Rasyid, Mansyur \& Suratno. 2009. Asesmen Perkembangan Anak Usia Dini. Yogyakarta: Multi Pressindo

Hurlock, Elizabeth B. 2011. Psikologi Perkembangan : Suatu Pendekatan Sepanjang Rentang Kehidupan. Jakarta : Erlangga.

Lexy J. Moleong, 2007. Metodologi Penelitian Kualitatif. Bandung : PT Remaja Rosdakarya Offset.

Lexy J. Moleong. 2010. Metodologi Penelitian Kualitatif. Bandung : PT Remaja Rosdakarya Offset.

Moh Nazir. 2003. Metode Penelitian. Jakarta : Ghalia Indonesia, 2003.

Nurdin Usman. 2002. Konteks Implementasi Berbasis Kurikulum.Jakarta : Grasindo.

Slamet Suyanto. 2005. Pembelajaran untuk Anak TK. Jakarta: Departemen Pendidikan Nasional Direktorat Pembinaan Pendidikan Tenaga Kependidikan Dan Ketenagaan Perguruan Tinggi.

Sugiyono. 2012. Metode Penelitian Kuantitatif Kualitatif dan R\&D. Bandung: Alfabeta.

Undang Undang SISDIKNAS 2003. 